\title{
Biodegradation and effect of formaldehyde and phenol on the denitrification process
}

M. Eiroa, A. Vilar, L. Amor, C. Kennes, M.C. Veiga

Water Research, Volume 39, Issues 2-3, January-February 2005, Pages 449-455

DOI: 10.1016/j.watres.2004.09.017

\begin{abstract}
Formaldehyde and phenol biodegradation during the denitrification process was studied at lab-scale, first in anoxic batch assays and then in a continuous anoxic reactor. The biodegradation of formaldehyde $\left(260 \mathrm{mg} \mathrm{l}^{-1}\right)$ as single carbon source and at phenol concentrations ranging from 30 to $580 \mathrm{mgl}^{-1}$ was investigated in batch assays, obtaining an initial biodegradation rate around $0.5 \mathrm{~g} \mathrm{CH}_{2} \mathrm{O} \mathrm{g} \mathrm{VSS}{ }^{-1} \mathrm{~d}^{-1}$. With regard to phenol, its complete biodegradation was only observed at initial concentrations of 30 and $180 \mathrm{mg} \mathrm{l}^{-1}$. The denitrification process was inhibited at phenol concentrations higher than $360 \mathrm{mg} \mathrm{l}^{-1}$. Studies were also done using a continuous anoxic upflow sludge blanket reactor in which formaldehyde removal efficiencies above $99.5 \%$ were obtained at all the applied formaldehyde loading rates, between 0.89 and $0.14 \mathrm{~g}$ COD $\left(\mathrm{CH}_{2} \mathrm{O}\right) \mathrm{l}^{-1} \mathrm{~d}^{-1}$. The phenol loading rate was increased from 0.03 to $1.3 \mathrm{~g}$ COD $\left(\mathrm{C}_{6} \mathrm{H}_{6} \mathrm{O}\right) \mathrm{l}^{-1} \mathrm{~d}^{-1}$. Phenol removal efficiencies above $90.6 \%$ were obtained at phenol concentrations in the influent between 27 and $755 \mathrm{mg} \mathrm{l}^{-1}$. However, when the phenol concentration was increased to $1010 \mathrm{mg} \mathrm{l}^{-1}$, its removal efficiency decreased. Denitrification percentages around $98.4 \%$ were obtained with phenol concentrations in the influent up to $755 \mathrm{mg} \mathrm{l}^{-1}$. After increasing phenol concentration to $1010 \mathrm{mg} \mathrm{l}^{-1}$, the denitrification percentage decreased because of the inhibition caused by phenol.
\end{abstract}

\section{Keywords}

Denitrification; Biodegradation; Formaldehyde; Phenol 


\section{Introduction}

Wastewaters from synthetic resin producing industries are characterized by the presence of high levels of organic matter and nitrogen compounds. Therefore, the treatment of these wastewaters requires the simultaneous removal of organic and nitrogen compounds, which can be undertaken by biological processes. The organic matter is present mainly as formaldehyde but odd effluents with high concentrations of phenol are also generated when the manufacturing process is changed. There are several references about formaldehyde biodegradation or phenol biodegradation separately under denitrifying conditions. However, it is interesting to analyze the simultaneous removal of formaldehyde and phenol and their effect on the denitrification process which is the purpose of this study.

Formaldehyde is a common compound in the chemical industry, used in a wide variety of processes and frequently found in wastewaters. Because of its toxicity, formaldehyde is often used as an active ingredient in preservatives and disinfectant agents to inhibit microbial activity. Therefore, its presence is expected to inhibit biological processes in wastewater treatment plants as well. However, formaldehyde is known to be biodegradable in both aerobic (Azachi et al., 1995; Yamazaki et al., 2001; Hidalgo et al., 2002) and anaerobic systems (Qu and Bhattacharya, 1997; Lu and Hegemann, 1998; Omil et al., 1999). In batch assays performed in our laboratory under nitrifying conditions, formaldehyde was completely biodegraded at concentrations between 30 and $3890 \mathrm{mg} \mathrm{l}^{-1}$ (Eiroa et al., 2004a). In other batch assays performed under denitrifying conditions, $430 \mathrm{mg} \mathrm{l}^{-1}$ formaldehyde was also completely biodegraded in the presence of urea concentrations between 90 and $370 \mathrm{mg} \mathrm{N} \mathrm{I}^{-1}$ (Eiroa et al., 2004b).

Phenol is a toxic compound also frequently found in effluents of different industries (resins, automobile, textile, pharmaceutical...). There are several references about phenol biodegradation in both aerobic (Buitrón et al., 1998; González et al., 2001a and González et al., 2001b) and anoxic conditions (Khoury et al., 1992; Fang and Zhou, 1997; Blaszczyk et al., 1998; Holub et al., 2000; Sarfaraz et al., 2004).

Biological nitrogen removal is carried out by nitrification and denitrification. During the nitrification step, ammonium is oxidized to nitrate under aerobic conditions; and during the denitrification step, nitrate is reduced to molecular nitrogen under anoxic conditions. For denitrification to take place, a source of organic carbon is required, which is the electron donor to be oxidized by nitrate. In the presence of toxic compounds, the biological nitrogen removal may be inhibited.

The aim of this research was to study the formaldehyde and phenol biodegradation and the effect of both compounds on the denitrification process. Therefore, anoxic assays at lab-scale were undertaken first in batch and then in a continuous reactor. The results can be used to optimize the operation of an industrial-scale wastewater treatment plant treating effluents which contain these pollutants. 


\section{Materials and methods}

\subsection{Analytical methods}

Formaldehyde was analyzed spectrophotometrically according to the Hantzch reaction (Nash, 1953), using a Perkin Elmer Lambda 11 UV/Vis spectrophotometer. Methanol was measured using a Hewlett Packard 5890-II gas chromatograph equipped with a Nukol column (30 m×0.25 mm ID) and a flame ionization detector. Nitrogen $\left(1.5 \mathrm{ml} \mathrm{min}^{-1}\right)$ was utilized as carrier gas. Injector and detector temperatures were 250 and $270{ }^{\circ} \mathrm{C}$, respectively. Phenol and formic acid were determined using a Hewlett Packard 1100 liquid chromatograph equipped with a C-18 ODS column $(25 \mathrm{~cm} \times 4 \mathrm{~mm}$ ID) and a UV diode-array detector. The mobile phases were methanol:water (60:40) and acetonitrile:phosphoric acid (80:20), respectively. Detection was performed at $280 \mathrm{~nm}$ for phenol and $210 \mathrm{~nm}$ for formic acid.

Nitrite and nitrate were analyzed by capillary electrophoresis using a Hewlett Packard ${ }^{3 \mathrm{D}} \mathrm{CE}$ system with a microcapillary tube of fused silica $(40 \mathrm{~cm} \times 50 \mu \mathrm{m}$ ID). UV detection was undertaken at a wavelength of $214 \mathrm{~nm}$ and $450 \mathrm{~nm}$ as reference.

Biogas composition $\left(\mathrm{N}_{2}, \mathrm{CH}_{4}, \mathrm{CO}_{2}\right.$ and $\mathrm{N}_{2} \mathrm{O}$ ) was analyzed on a Hewlett Packard 5890II gas chromatograph equipped with a Porapack Q W80/100 column ( $2 \mathrm{~m} \times 1 / 8^{\prime \prime}$ ID) and a thermal conductivity detector. Helium $\left(15 \mathrm{ml} \mathrm{min}^{-1}\right)$ was utilized as carrier gas. Injector, oven and detector temperatures were 90,25 and $100^{\circ} \mathrm{C}$, respectively.

$\mathrm{pH}$, COD, total suspended solids (TSS) and volatile suspended solids (VSS) were evaluated according to Standard Methods ( APHA, 1998).

\subsection{Batch assays}

After some preliminary experiments that allowed defining the most appropriate operating conditions, denitrifying batch assays were undertaken in $300 \mathrm{ml}$ vials filled with $250 \mathrm{ml}$ medium. Each flask was inoculated with $2 \mathrm{~g} \mathrm{VSS} \mathrm{l}^{-1}$, using sludge obtained from the anoxic chamber of the full-scale wastewater treatment plant of a synthetic resin producing factory (Cantó et al., 1998). The initial $\mathrm{pH}$ was adjusted to 7.5; $\mathrm{NaHCO}_{3}$ was used as $\mathrm{pH}$ buffer. The medium was supplemented with $2.5 \mathrm{ml}$ nutrient solution composed of $\left(\mathrm{g} \mathrm{l}^{-1}\right): \mathrm{CaCl}_{2} \cdot 2 \mathrm{H}_{2} \mathrm{O} \quad 1.00, \quad \mathrm{FeSO}_{4} \cdot 7 \mathrm{H}_{2} \mathrm{O} \quad 0.50, \mathrm{MnCl}_{2} \cdot 4 \mathrm{H}_{2} \mathrm{O} \quad 0.25$, $\left(\mathrm{NH}_{4}\right)_{6} \mathrm{Mo}_{7} \mathrm{O}_{24} \cdot 4 \mathrm{H}_{2} \mathrm{O} \quad 0.05, \mathrm{CuSO}_{4} \cdot 5 \mathrm{H}_{2} \mathrm{O} 0.05, \mathrm{MgSO}_{4} \cdot 7 \mathrm{H}_{2} \mathrm{O} 2.40$ and $\mathrm{CoCl}_{2} \cdot 6 \mathrm{H}_{2} \mathrm{O}$ 0.001 . $\mathrm{NH}_{4} \mathrm{Cl}$ and $\mathrm{KH}_{2} \mathrm{PO}_{4}$ were added in order to obtain a COD/N/P ratio of 200/5/1. Then, nitrate (240 $\mathrm{mg} \mathrm{N}^{-1}$ ), formaldehyde $\left(260 \mathrm{mg} \mathrm{l}^{-1}\right.$ ) and phenol were added in order to study the denitrification process and formaldehyde and phenol biodegradation. Phenol concentrations ranging from 30 to $580 \mathrm{mg} \mathrm{l}^{-1}$ were assayed. Finally, the flasks were sealed and nitrogen gas was passed through the head space for $5 \mathrm{~min}$ in order to remove oxygen. Formaldehyde, phenol, nitrite and nitrate concentrations were measured at different time intervals. Assays were performed in a thermostatic chamber at $20^{\circ} \mathrm{C}$ and with constant shaking at $200 \mathrm{rpm}$. All experiments were carried out in duplicate.

\subsection{Continuous reactor}

A lab-scale anoxic upflow sludge blanket reactor, made of glass with a length of $45 \mathrm{~cm}$, an inner diameter of $5.5 \mathrm{~cm}$ and an effective volume of $0.92 \mathrm{l}$, was used for continuous 
assays. The system was provided with a liquid displacement biogas measurement device (Veiga et al., 1990).

The reactor was inoculated with $8.5 \mathrm{~g} \mathrm{VSS} \mathrm{l}^{-1}$ of anoxic sludge obtained from the same plant than in batch assays. The influent was supplied to the reactor by a peristaltic pump at $0.51 \mathrm{l} \mathrm{d}^{-1}$ and a recirculation rate of $7.7 \mathrm{l} \mathrm{d}^{-1}$ was used. The hydraulic retention time was 1.8 days. The influent consisted of a synthetic solution containing $\mathrm{CH}_{2} \mathrm{O}, \mathrm{C}_{6} \mathrm{H}_{6} \mathrm{O}$, $\mathrm{KNO}_{3}, \mathrm{NH}_{4} \mathrm{Cl}, \mathrm{KH}_{2} \mathrm{PO}_{4}, \mathrm{~K}_{2} \mathrm{HPO}_{4}$ and $10 \mathrm{ml} \mathrm{l}^{-1}$ of the nutrient solution mentioned before. Nitrate concentration in the influent was maintained at $400 \mathrm{mg} \mathrm{N} \mathrm{I}^{-1}$, while formaldehyde concentration was decreased from 1505 to $0 \mathrm{mg} \mathrm{l}^{-1}$ and phenol concentration was increased from 27 to $1010 \mathrm{mg} \mathrm{l}^{-1}$. Initially, the COD/N ratio was maintained between 4 and 4.5. It was later increased to 6 .

\section{Results and discussion}

\subsection{Batch assays}

\subsubsection{Formaldehyde biodegradation}

In batch assays, biodegradation of $260 \mathrm{mg} \mathrm{l}^{-1}$ formaldehyde was studied as the sole carbon source and at phenol concentrations ranging from 30 to $580 \mathrm{mg} \mathrm{l}^{-1}$. Complete formaldehyde biodegradation took place in less than $24 \mathrm{~h}$ (data not shown). The initial biodegradation rates remained almost constant around $0.5 \mathrm{~g} \mathrm{CH}_{2} \mathrm{O} \mathrm{g} \mathrm{VSS}{ }^{-1} \mathrm{~d}^{-1}$ in all assays, indicating that formaldehyde removal was not affected by the initial phenol concentration. The phenol biodegradation took place after formaldehyde was completely removed.

\subsubsection{Phenol biodegradation}

In order to study phenol biodegradation, assays with concentrations ranging from 30 to $580 \mathrm{mg} \mathrm{l}^{-1}$ phenol in the presence of $260 \mathrm{mg} \mathrm{l}^{-1}$ formaldehyde and assays with $180 \mathrm{mg} \mathrm{l}^{-1}$ phenol without formaldehyde were undertaken. The evolution of phenol concentration in the assays is shown in Fig. 1. While formaldehyde was completely removed during the first day in all assays, phenol biodegradation did not begin until the third day for the lowest concentration $\left(30 \mathrm{mg} \mathrm{l}^{-1}\right.$ ). Therefore, there was no simultaneous removal of both compounds because an acclimation period of the sludge to phenol was necessary. Complete phenol removal took only place in assays with initial concentrations of 30 and $180 \mathrm{mg} \mathrm{l}^{-1}$ and phenol biodegradation was not affected by the presence or absence of formaldehyde. In assays with $360 \mathrm{mg} \mathrm{l}^{-1}$ phenol, a removal of $33.7 \%$ was obtained after 36 days and with $580 \mathrm{mg} \mathrm{l}^{-1}$ phenol, its biodegradation was completely inhibited. If the biomass was adapted to the presence of phenol, the concentrations which cause inhibition could be higher. But the presence of phenol is irregular in wastewaters from synthetic resin producing industries. Therefore, it is difficult to find biomass adapted to phenol. 


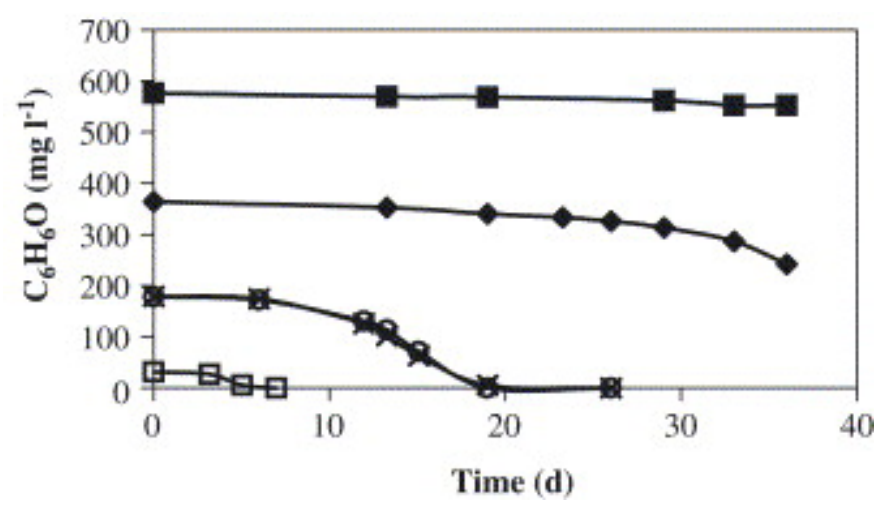

Fig. 1.

Phenol biodegradation in presence of formaldehyde (260 $\left.\mathrm{mg} \mathrm{CH}_{2} \mathrm{Ol}^{-1}\right)$ : (口) 30, (×) 180, (•) 360 and (-) $580 \mathrm{mg} \mathrm{C}_{6} \mathrm{H}_{6} \mathrm{Ol}^{-1}$ and (०) $180 \mathrm{mg} \mathrm{C}_{6} \mathrm{H}_{6} \mathrm{O} \mathrm{l}^{-1}$ without formaldehyde.

Blaszczyk et al. (1998) also studied phenol biodegradation in denitrifying conditions, performing batch assays at $30^{\circ} \mathrm{C}$. Phenol in concentrations up to $500 \mathrm{mg} \mathrm{l}^{-1}$ was degraded without lag phase; however, at higher concentrations (up to $1000 \mathrm{mg} \mathrm{l}^{-1}$ ) the activity of the bacteria was preceded by a lag phase of 9 to 15 days. The phenol concentrations which were removed are higher than in our study and the lag phases are shorter. This can be due to the temperature because their assays were undertaken at $30{ }^{\circ} \mathrm{C}$ and ours at $20^{\circ} \mathrm{C}$ and the activity of the microorganisms decreases at lower temperatures. Another cause can be the adaptation of their bacteria to the presence of phenol since they were maintained during 3 years in a medium with phenol as carbon source and nitrate as electron acceptor.

\subsubsection{Denitrification in presence of formaldehyde and phenol}

Biological denitrification in presence of formaldehyde (260 $\mathrm{mg} \mathrm{l}^{-1}$ ) and different phenol concentrations (between 30 and $580 \mathrm{mg} \mathrm{l}^{-1}$ ) was investigated in batch assays. The nitrate concentrations are shown in Fig. 2. Nitrite is not presented because it was only detected (up to $12.2 \mathrm{mg} \mathrm{N}^{-1}$ ) in assays with the highest phenol concentration (580 $\mathrm{mg} \mathrm{l}^{-1}$ ). The $\mathrm{pH}$ was between 7.5 and 8 . In all assays a decrease in the nitrate concentration can be observed.

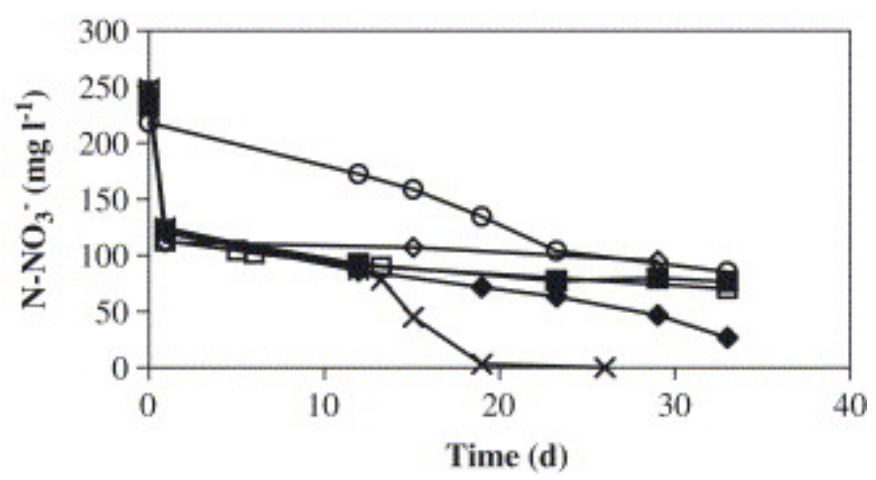

Fig. 2.

Denitrification process in presence of formaldehyde $\left(260 \mathrm{mg} \mathrm{CH}_{2} \mathrm{Ol}^{-1}\right)$ and different phenol

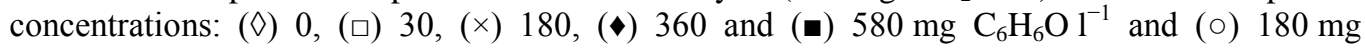
$\mathrm{C}_{6} \mathrm{H}_{6} \mathrm{Ol}^{-1}$ without formaldehyde. 
Two different substrates were used as carbon source and it seems that the denitrification process took place in two stages. In a first stage, formaldehyde was used as carbon source since the denitrification took place at the same time than the formaldehyde biodegradation. In a second stage, after the formaldehyde removal, phenol was used as carbon source in the denitrification process. However, in this second stage the denitrification rate was much lower. This process in two stages can also be corroborated considering that in the assays with formaldehyde or phenol as the sole carbon source only one stage was observed.

In all assays with formaldehyde the same denitrification percentage was found in the first stage, around $51.2 \%$. Once formaldehyde was removed it is necessary to take into account the amount of phenol present and the remaining nitrate concentration to explain the different denitrification percentages. There was complete denitrification only in the assays with $180 \mathrm{mg} \mathrm{l}^{-1}$ phenol and $260 \mathrm{mg} \mathrm{l}^{-1}$ formaldehyde, and phenol inhibition was not observed. In the assays with $30 \mathrm{mg} \mathrm{l}^{-1}$ phenol and $260 \mathrm{mg} \mathrm{l}^{-1}$ formaldehyde and in the assays with $180 \mathrm{mg} \mathrm{l}^{-1}$ phenol without formaldehyde, complete denitrification did not take place because of the lack of carbon source but phenol was completely removed. In the assays with $360 \mathrm{mg} \mathrm{l}^{-1}$ phenol and $260 \mathrm{mg} \mathrm{l}^{-1}$ formaldehyde and in the assays with $580 \mathrm{mg} \mathrm{l}^{-1}$ phenol and $260 \mathrm{mg} \mathrm{l}^{-1}$ formaldehyde, in which there was enough organic matter, complete denitrification did not take place probably due to an inhibition caused by phenol. Therefore, the denitrification process was inhibited at phenol concentrations higher than $360 \mathrm{mg} \mathrm{l}^{-1}$.

Holub et al. (2000) studied the denitrification process in presence of phenol by petroleum refining sediments. Incubation of sediments at 30 and $55{ }^{\circ} \mathrm{C}$ in a medium with phenol $\left(500 \mathrm{mg} \mathrm{l}^{-1}\right.$ ) and nitrate $\left(535 \mathrm{mg} \mathrm{N}^{-1}\right.$ ) resulted in complete reduction of nitrate accompanied by accumulation of nitrite, reaching 115 and $275 \mathrm{mg} \mathrm{N} \mathrm{l}^{-1}$ for 30 and $55{ }^{\circ} \mathrm{C}$, respectively. In our study, nitrite did not accumulate in spite of the lack of carbon source, except for assays with the highest phenol concentration (580 $\mathrm{mg} \mathrm{l}^{-1}$ ) in which concentrations up to $12.2 \mathrm{mg} \mathrm{N} \mathrm{I}^{-1}$ nitrite were detected.

\subsection{Continuous reactor}

\subsubsection{Formaldehyde biodegradation}

The amount of phenol in the influent of the continuous lab-scale reactor was increased stepwise to study its biodegradation. Therefore, in order to maintain the COD/N ratio between 4 and 4.5, the formaldehyde concentration in the influent was varied between 1505 and $235 \mathrm{mg} \mathrm{l}^{-1}$. The evolution of its concentration in the influent and effluent of the reactor is presented in Fig. 3A, the vertical line indicates the change in the COD/N ratio from 4-4.5 to 6 (day of operation 203). Formaldehyde removal efficiencies above 99.5\% were obtained at all the applied formaldehyde loading rates, between 0.89 and $0.14 \mathrm{~g}$ COD $\left(\mathrm{CH}_{2} \mathrm{O}\right) \mathrm{l}^{-1} \mathrm{~d}^{-1}$. The unit showed high formaldehyde biodegradation levels, its concentration in the effluent always being below $2.8 \mathrm{mg} \mathrm{l}^{-1}$, with a mean value of $0.7 \mathrm{mg} \mathrm{l}^{-1}$. Formaldehyde biodegradation was not affected by the phenol loading rate applied to the system. Consequently, the continuous anoxic removal of formaldehyde is possible in presence of phenol, as in the case of wastewaters from synthetic resin producing factories. 

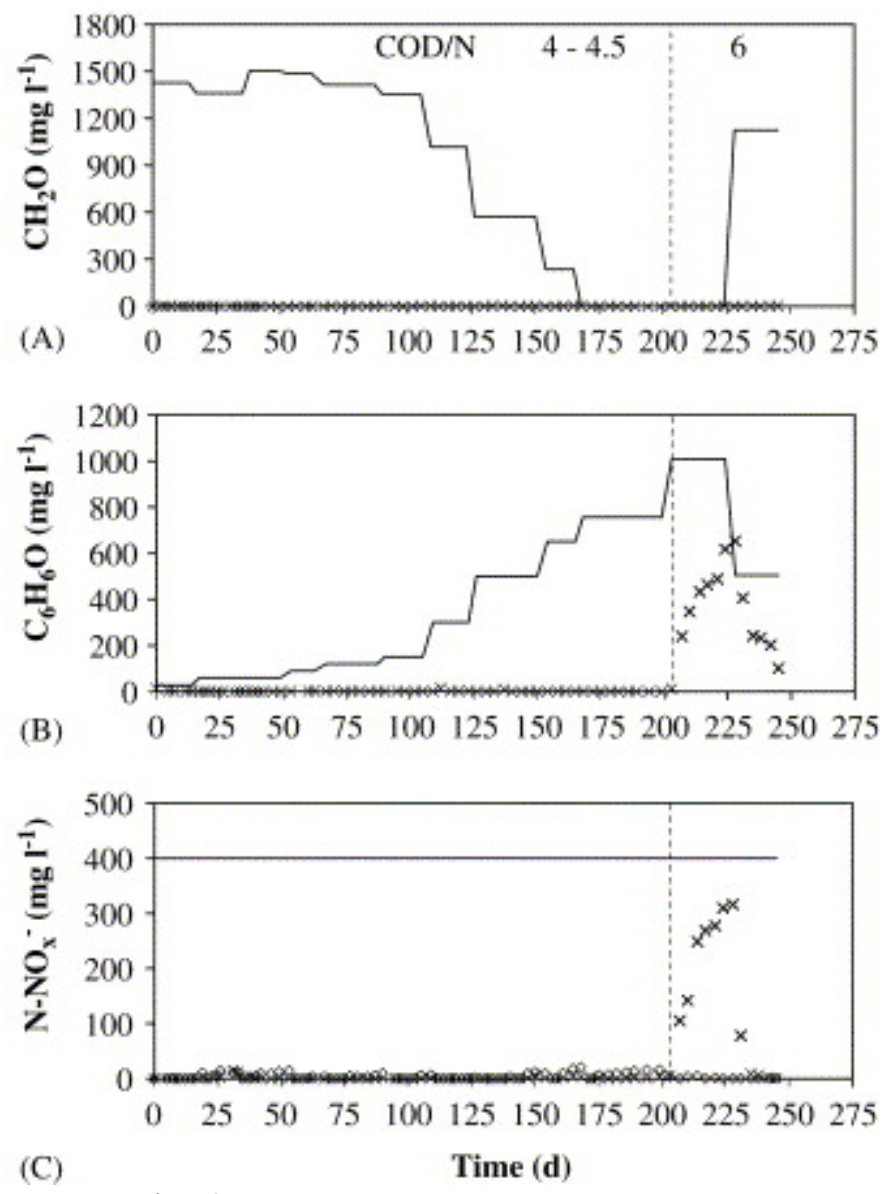

Fig. 3.

(A) Formaldehyde concentration in the influent $(-)$ and effluent $(\times)$ of the continuous reactor. (B) Phenol concentration in the influent $(-)$ and effluent $(\times)$ of the continuous reactor. (C) Nitrate in the influent $(-)$ and nitrate $(\times)$ and nitrite $(\diamond)$ in the effluent of the continuous reactor (hydraulic retention time $=1.8$ days).

After day of operation 228, when the formaldehyde in the influent was changed from 0 to $1125 \mathrm{mg} \mathrm{l}^{-1}$, in order to maintain the $\mathrm{COD} / \mathrm{N}$ ratio and decrease the phenol concentration, methanol and formic acid were detected in the effluent. Their concentrations increased up to around $130 \mathrm{mg} \mathrm{CH}_{3} \mathrm{OH} \mathrm{l}^{-1}$ and $190 \mathrm{mg} \mathrm{HCOOH} \mathrm{l}^{-1}$, decreasing below the detection limits in less than 7 days. Similar assays performed in our laboratory with the same sludge proved that formaldehyde was transformed into methanol and formic acid. This is in agreement with results obtained by Kato et al. (1983) studying aerobic formaldehyde biodegradation by Pseudomonas putida F61. They found an enzyme which catalyzed dismutation of formaldehyde to form methanol and formic acid. Adroer et al. (1990) studied the mechanism of aerobic formaldehyde biodegradation by a strain of $P$. putida. Their results indicated that the biodegradation led to the simultaneous appearance of methanol and formic acid. The degradation of methanol and formic acid began after exhaustion of formaldehyde in the medium. 


\subsubsection{Phenol biodegradation}

With the purpose of studying phenol biodegradation in the continuous lab-scale reactor, its concentration in the influent was increased from 27 to $1010 \mathrm{mg} \mathrm{l}^{-1}$. However, the nitrate concentration was maintained constant at $400 \mathrm{mg} \mathrm{N} \mathrm{l}^{-1}$ during all the operation period. The evolution of phenol concentration in the influent and effluent of the reactor is shown in Fig. 3B. Until day of operation 203, the applied COD/N ratio was maintained between 4 and 4.5 by decreasing the formaldehyde concentration and increasing stepwise the phenol concentration in the influent (up to $755 \mathrm{mg} \mathrm{l}^{-1}$ ). Phenol removal efficiencies above $90.6 \%$ were obtained at all the applied phenol loading rates, between 0.03 and $1.0 \mathrm{~g}$ COD $\left(\mathrm{C}_{6} \mathrm{H}_{6} \mathrm{O}\right) \mathrm{l}^{-1} \mathrm{~d}^{-1}$. Phenol concentration in the effluent was always below $15.3 \mathrm{mg} \mathrm{l}^{-1}$, with a mean value of $1.4 \mathrm{mg} \mathrm{l}^{-1}$.

When $100 \%$ phenol was present in the influent at the COD/ $\mathrm{N}$ ratio of 4.5 (day of operation 203), this ratio was increased to 6 by increasing the phenol concentration to $1010 \mathrm{mg} \mathrm{l}^{-1}$ as single carbon source $\left(1.3 \mathrm{~g}\right.$ COD $\left.\left(\mathrm{C}_{6} \mathrm{H}_{6} \mathrm{O}\right) \mathrm{l}^{-1} \mathrm{~d}^{-1}\right)$. In these conditions, its concentration in the effluent began to increase, reaching $650 \mathrm{mg} \mathrm{l}^{-1}$. Therefore, phenol caused inhibition at that concentration. Consequently, it was decided to maintain the $\mathrm{COD} / \mathrm{N}$ ratio but decreasing the phenol concentration to $505 \mathrm{mg} \mathrm{l}^{-1}$ and adding formaldehyde in the influent (day of operation 228). Under these conditions, the system recovered in few days and the phenol concentration decreased in the effluent, corroborating that the inhibition was caused by the high phenol concentration in the influent (1010 $\left.\mathrm{mg} \mathrm{l}^{-1}\right)$.

Therefore, the anoxic phenol removal at organic loading rates up to $1.0 \mathrm{~g}$ COD $\left(\mathrm{C}_{6} \mathrm{H}_{6} \mathrm{O}\right) \mathrm{l}^{-1} \mathrm{~d}^{-1}\left(0.42 \mathrm{~g} \mathrm{C}_{6} \mathrm{H}_{6} \mathrm{O} \mathrm{l^{-1 }} \mathrm{d}^{-1}\right)$ was possible. However, when the organic loading rate was increased to $1.3 \mathrm{~g} \mathrm{COD}\left(\mathrm{C}_{6} \mathrm{H}_{6} \mathrm{O}\right) \mathrm{l}^{-1} \mathrm{~d}^{-1}\left(0.56 \mathrm{~g} \mathrm{C}_{6} \mathrm{H}_{6} \mathrm{O} \mathrm{l^{-1 }} \mathrm{d}^{-1}\right)$, phenol caused inhibition and its removal efficiency decreased. These data indicate that the continuous anoxic treatment of wastewaters with high levels of phenol in the presence of formaldehyde can be undertaken, although it is necessary to control the phenol concentration applied to the system.

Other authors worked with phenol at higher organic loading rates but using much lower concentrations. Fang and Zhou (1997) studied the phenol biodegradation under denitrifying conditions in an upflow packed reactor at $30{ }^{\circ} \mathrm{C}$ using synthetic wastewater. At a hydraulic retention time of $0.52 \mathrm{~h}$, using a feed containing $223 \mathrm{mg} \mathrm{N}^{-1}$ nitrate, $100 \mathrm{mg} \mathrm{l}^{-1}$ phenol, $50 \mathrm{mg} \mathrm{l}^{-1} \mathrm{~m}$-cresol and $500 \mathrm{mg} \mathrm{l}^{-1}$ sucrose, they reached a biodegradation rate of $4.3 \mathrm{~g} \mathrm{C}_{6} \mathrm{H}_{6} \mathrm{O} \mathrm{l}^{-1} \mathrm{~d}^{-1}$. This rate is higher than in our study but the phenol concentration in the influent was much lower.

Blaszczyk et al. (1998) also analyzed phenol biodegradation under denitrifying conditions in a packed reactor. These authors, performing studies at different phenol concentrations in the influent (from 200 to $2000 \mathrm{mg} \mathrm{l}^{-1}$ ) and different temperatures (13, 20 and $30^{\circ} \mathrm{C}$ ), concluded that phenol biodegradation is dependent on both parameters. Phenol removal is less efficient when its concentration in the influent increases or the temperature decreases. The highest biodegradation rate, obtained using a phenol concentration in the influent of $200 \mathrm{mg} \mathrm{l}^{-1}$ and operating the reactor at $30^{\circ} \mathrm{C}$ and a hydraulic retention time of $2 \mathrm{~h}$, was $2.5 \mathrm{~g} \mathrm{C}_{6} \mathrm{H}_{6} \mathrm{O} \mathrm{l}^{-1} \mathrm{~d}^{-1}$. 
Other authors (Sarfaraz et al., 2004) studied phenol removal in anoxic conditions at $30{ }^{\circ} \mathrm{C}$ using a sequencing batch reactor. They achieved more than $80 \%$ phenol removal for concentrations up to $1050 \mathrm{mg} \mathrm{l}^{-1}$ and cycle lengths of $6 \mathrm{~h}\left(2.7 \mathrm{~g} \mathrm{C}_{6} \mathrm{H}_{6} \mathrm{O} \mathrm{l}^{-1} \mathrm{~d}^{-1}\right)$. However, when the concentration was increased to $1150 \mathrm{mg} \mathrm{l}^{-1}$, phenol removal efficiency decreased to $56 \%$ (3.1 $\left.\mathrm{g} \mathrm{C}_{6} \mathrm{H}_{6} \mathrm{O} \mathrm{l}^{-1} \mathrm{~d}^{-1}\right)$.

In our study, formaldehyde and phenol were almost completely removed under anoxic conditions until day of operation 203. However, a COD fraction of the influent was present in the effluent of the unit. The mean percentage of remaining COD in the effluent was $4.2 \%$ and could be due to extra enzymes or inert bio-products released from the sludge in the reactor. After day of operation 203, the COD in the effluent increased as a consequence of the increase in the phenol concentration. The highest COD reached in the effluent was $1547 \mathrm{mg} \mathrm{l}^{-1}$, corresponding to $650 \mathrm{mg} \mathrm{l}^{-1}$ phenol, which is in agreement with the obtained data.

\subsubsection{Denitrification in presence of formaldehyde and phenol}

Biological denitrification in presence of formaldehyde and phenol was also studied in the continuous lab-scale reactor. The evolution of nitrate and nitrite concentrations is presented in Fig. 3C. The applied COD/N ratio was maintained between 4 and 4.5 until day of operation 203 and afterwards it was increased to 6 . The nitrate concentration in the influent was maintained constant at $400 \mathrm{mg} \mathrm{N}^{-1}$ during all the operation period, applying a nitrogen loading rate of $0.22 \mathrm{~g} \mathrm{~N}-\mathrm{NO}_{3}{ }^{-} \mathrm{l}^{-1} \mathrm{~d}^{-1}$. With phenol concentrations in the influent up to $755 \mathrm{mg} \mathrm{l}^{-1}$ (day of operation 203), denitrification percentages above 93.4\% were obtained, being the mean denitrification efficiency of $98.4 \%$. The nitrate and nitrite concentrations in the effluent were always lower than 14.9 and $20.8 \mathrm{mg} \mathrm{N}^{-1}$, respectively. Consequently, formaldehyde and phenol were efficiently used as electron donors for denitrification.

After increasing the phenol concentration in the influent to $1010 \mathrm{mg} \mathrm{l}^{-1}$ (day of operation 203), the nitrate concentration in the effluent increased up to $315 \mathrm{mg} \mathrm{N}^{-1}$, remaining unchanged the nitrite concentration. The denitrification percentage decreased to $21.2 \%$ when it was decided to decrease the phenol concentration to $505 \mathrm{mg} \mathrm{l}^{-1}$ and add formaldehyde in the influent (day of operation 228). Under these conditions the denitrification percentage recovered. Therefore, the denitrification percentage decreased because of the inhibition caused by phenol.

An important parameter in the control of biological processes is the $\mathrm{pH}$. Its value in the effluent of the continuous reactor was between 7.6 and 8.6, with a mean value of 8.2, except when the phenol concentration in the effluent increased in which case $\mathrm{pH}$ decreased to 7.1. This was because the decrease in the denitrification percentage caused a lower production of alkalinity. When the denitrification percentage was recovered, the $\mathrm{pH}$ was also recovered.

The biogas composition was periodically analyzed as shown in Fig. 4. In the first days of operation, the nitrogen percentage increased and the carbon dioxide and methane percentages decreased. When the system was stable, the percentages of nitrogen, carbon dioxide and methane in the biogas varied between $80.5 \%$ and $98.0 \%, 0.04 \%$ and $10.0 \%$ and 0 and $4.0 \%$, respectively. Nitrous oxide was never detected in the gas phase. 
Although the methane percentage was low, it indicates that the sludge retained a certain methanogenic activity even after working under anoxic conditions during a long time.

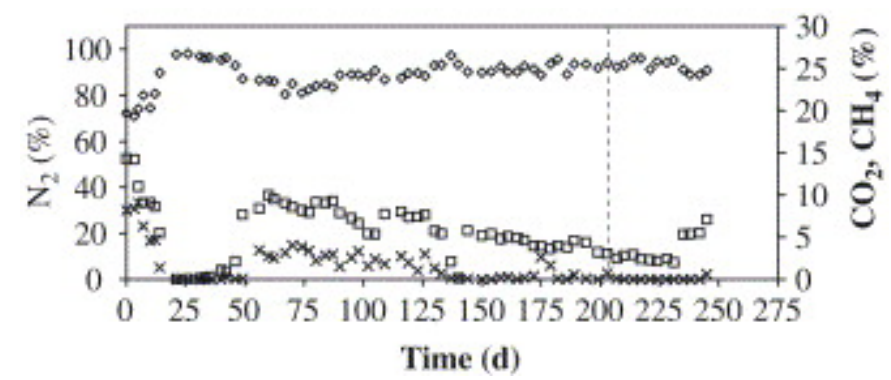

Fig. 4.

Evolution of biogas composition: nitrogen $(\diamond)$, carbon dioxide $(\square)$ and methane $(\times)$.

The biomass concentration in the reactor increased from an initial value of 8.5 to $13.1 \mathrm{~g}$ VSS $^{-1}$ until day of operation 137. That same day, biomass was purged from the reactor, remaining $7.6 \mathrm{~g} \mathrm{VSS} \mathrm{l}^{-1}$. Afterwards, its concentration increased to $10.1 \mathrm{~g}$ VSS $^{-1}$ until the end of the operation (day 245). With regard to biomass in the effluent (Fig. 5), its concentration decreased during the first days of operation. When the system was stable and until day of operation 203, the biomass in the effluent varied between 0.006 and $0.024 \mathrm{~g} \mathrm{VSS}^{-1}$, with a mean value of $0.016 \mathrm{~g} \mathrm{VSS} \mathrm{l}^{-1}$. Therefore, sludge with very good settling properties and a satisfactory effluent with very low concentrations of suspended solids were obtained. However, several incidents of sludge flotation took place; retention of gas bubbles was observed during the operation, causing flotation of the sludge. After increasing the phenol concentration in the influent to $1010 \mathrm{mg} \mathrm{l}^{-1}$ (day of operation 203), the biomass concentration in the effluent increased since the system was destabilized. During this period the biomass concentration in the effluent varied between 0.022 and $0.074 \mathrm{~g} \mathrm{VSS} \mathrm{l}^{-1}$.

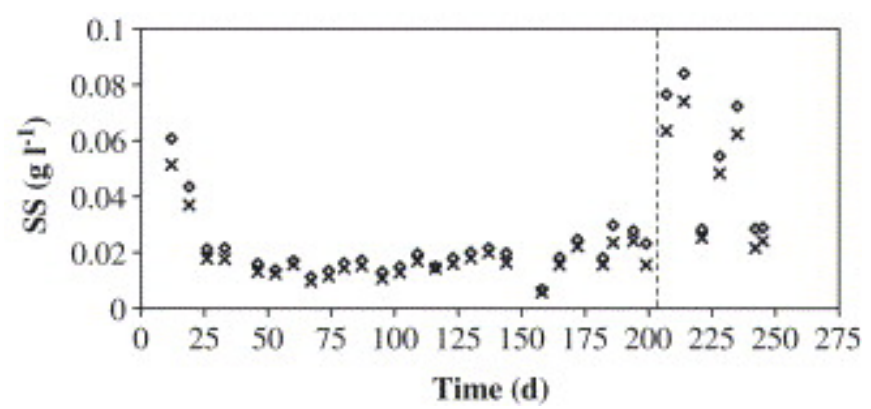

Fig. 5.

TSS $(\diamond)$ and VSS $(\times)$ in the effluent of the continuous reactor. 


\section{Conclusions}

\subsection{Batch assays}

Formaldehyde removal was not affected by the presence of different phenol concentrations. Complete formaldehyde biodegradation $\left(260 \mathrm{mg} \mathrm{l}^{-1}\right.$ ) took place in all assays. The initial biodegradation rate remained almost constant, around $0.5 \mathrm{~g}$ $\mathrm{CH}_{2} \mathrm{O}$ g VSS ${ }^{-1} \mathrm{~d}^{-1}$, at phenol concentrations ranging from 30 to $580 \mathrm{mg} \mathrm{l}^{-1}$.

Phenol caused inhibition and an acclimation period of the sludge was necessary. Complete phenol removal took only place in assays with initial concentrations of 30 and $180 \mathrm{mg} \mathrm{l}^{-1}$. At higher concentrations (360 and $580 \mathrm{mg} \mathrm{l}^{-1}$ ) inhibition of its biodegradation was observed (using non-adapted biomass). The denitrification process was inhibited at phenol concentrations higher than $360 \mathrm{mg} \mathrm{l}^{-1}$.

\subsection{Continuous reactor}

The nitrate concentration in the influent was maintained at $400 \mathrm{mg} \mathrm{N} \mathrm{l}^{-1}$, while formaldehyde concentration was decreased from 1505 to $0 \mathrm{mg} \mathrm{l}^{-1}$ and phenol concentration was increased from 27 to $1010 \mathrm{mg} \mathrm{l}^{-1}$. Formaldehyde removal efficiencies above 99.5\% were obtained at all the applied formaldehyde loading rates, between 0.89 and $0.14 \mathrm{~g}$ COD $\left(\mathrm{CH}_{2} \mathrm{O}\right) \mathrm{l}^{-1} \mathrm{~d}^{-1}$. The formaldehyde biodegradation was not affected by the applied phenol loading rate.

The phenol loading rate was increased from 0.03 to $1.3 \mathrm{~g} \mathrm{COD}\left(\mathrm{C}_{6} \mathrm{H}_{6} \mathrm{O}\right) \mathrm{l}^{-1} \mathrm{~d}^{-1}$. Phenol removal efficiencies above $90.6 \%$ were obtained at phenol concentrations in the influent up to $755 \mathrm{mg} \mathrm{l}^{-1}$. However, when the phenol concentration was increased to $1010 \mathrm{mg}$ $\mathrm{l}^{-1}$, its removal efficiency decreased.

With regard to the denitrification process, percentages around $98.4 \%$ were obtained with phenol concentrations in the influent up to $755 \mathrm{mg} \mathrm{l}^{-1}$. After increasing the phenol concentration to $1010 \mathrm{mg} \mathrm{l}^{-1}$, the denitrification percentage decreased because of the inhibition caused by phenol.

These data indicate that the continuous anoxic treatment of wastewaters with high levels of phenol in the presence of formaldehyde and nitrate can be undertaken, although it is necessary to control the phenol concentration applied to the system.

\section{Acknowledgements}

The present research has been funded by Projects REN2000-0218-P4-02 and PPQ200202882, Spanish Ministry of Science and Technology and Project PGIDIT03PXIC10304PN, Xunta de Galicia. M. Eiroa is grateful to the Spanish Ministry of Education and Culture for a fellowship. 


\section{References}

N. Adroer, C. Casas, C. de Mas, C. Solà

Mechanism of formaldehyde biodegradation by Pseudomonas putida

Appl. Microbiol. Biotechnol., 33 (1990), pp. 217-220

APHA, 1998. Standard Methods for the Examination of Water and Wastewater, 20th ed. Washington, DC, USA.

M. Azachi, Y. Henis, A. Oren, P. Gurevich, S. Sarig Transformation of formaldehyde by a Halomonas sp

Can. J. Microbiol., 41 (1995), pp. 548-553

M. Blaszczyk, M. Przytocka-Jusiak, A. Suszek, A. Mielcarek

Microbial degradation of phenol in denitrifying conditions

Acta Microbiol. Polon., 47 (1) (1998), pp. 65-75

G. Buitrón, A. González, L.M. López-Marín

Biodegradation of phenolic compounds by an acclimated activated sludge and isolated bacteria

Water Sci. Technol., 37 (4-5) (1998), pp. 371-378

Cantó, M., Gómez, J., Kennes, C., Veiga, M.C., 1998. Integrated anoxic-aerobic treatment of wastewaters from a synthetic resin producing factory. European Conference on New Advances in Biological Nitrogen and Phosphorus Removal for Municipal or Industrial Wastewaters, Narbonne, France, pp. 289-292.

M. Eiroa, C. Kennes, M.C. Veiga

Formaldehyde biodegradation and its inhibitory effect on nitrification

J. Chem. Technol. Biotechnol., 79 (2004), pp. 499-504

M. Eiroa, C. Kennes, M.C. Veiga

Formaldehyde and urea removal in a denitrifying granular sludge blanket reactor

Water Res., 38 (2004), pp. 3495-3502

H.H.P. Fang, G.M. Zhou

Denitrification of phenolic wastewater by immobilized sludge

Environ. Technol., 18 (1997), pp. 827-834

G. González, G. Herrera, M.T. García, M. Peña

Biodegradation of phenol in a continuous process: comparative study of stirred tank and fluidized-bed bioreactors

Bioresour. Technol., 76 (2001), pp. 245-251

G. González, G. Herrera, M.T. García, M. Peña

Biodegradation of phenolic industrial wastewater in a fluidized bed bioreactor with immobilized cells of Pseudomonas putida

Bioresour. Technol., 80 (2001), pp. 137-142 
A. Hidalgo, A. Lopategi, M. Prieto, J.L. Serra, M.J. Llama

Formaldehyde removal in synthetic and industrial wastewater by Rhodococcus erythropolis UPV-1

Appl. Microbiol. Biotechnol., 58 (2002), pp. 260-263

W. Holub, M. Przytocka-Jusiak, M. Blaszczyk, R. Mycielski

Nitrite as agent selecting anaerobic phenol-degrading microflora in petroleum refining sediments

Water Res., 34 (4) (2000), pp. 1354-1358

N. Kato, K. Shirakawa, H. Kobayashi, C. Sakazawa

The dismutation of aldehydes by a bacterial enzyme

Agric. Biol. Chem., 47 (1) (1983), pp. 39-46

N. Khoury, W. Dott, P. Kampfer

Anaerobic degradation of phenol in batch and continuous cultures by a denitrifying bacterial consortium

Appl. Microbiol. Biotechnol., 37 (1992), pp. 524-528

Z. Lu, W. Hegemann

Anaerobic toxicity and biodegradation of formaldehyde in batch cultures

Water Res., 32 (1) (1998), pp. 209-215

T. Nash

The colorimetric estimation of formaldehyde by means of the Hantzch reaction

Biochem. J., 55 (1953), pp. 416-421

F. Omil, D. Méndez, G. Vidal, R. Méndez, J.M. Lema

Biodegradation of formaldehyde under anaerobic conditions

Enzyme Microbiol. Technol., 24 (1999), pp. 255-262

M. Qu, S.K. Bhattacharya

Toxicity and biodegradation of formaldehyde in anaerobic methanogenic culture

Biotechnol. Bioeng., 55 (5) (1997), pp. 727-736

S. Sarfaraz, S. Thomas, U.K. Tewari, L. Iyengar

Anoxic treatment of phenolic wastewater in sequencing batch reactor

Water Res., 38 (2004), pp. 965-971

M.C. Veiga, M. Soto, R. Méndez, J.M. Lema

A new device for measurement and control of gas production by bench scale anaerobic digesters

Water Res., 24 (12) (1990), pp. 1551-1554

T. Yamazaki, W. Tsugawa, K. Sode

Biodegradation of formaldehyde by a formaldehyde-resistant bacterium isolated from seawater

Appl. Biochem. Biotechnol., 91-93 (2001), pp. 213-217 